\title{
Molecular characterization and genetic relationships among most common identified morphotypes of critically endangered rare Moroccan species Argania spinosa (Sapotaceae) using RAPD and SSR markers
}

\author{
Khalid MaJourhat $^{1,2}$, Youssef JABbar ${ }^{1}$, Abdellatif HAFIdi ${ }^{1}$, Pedro MARTíneZ-GómeZ ${ }^{2 *}$ \\ ${ }^{1}$ Faculté des Sciences Semlalia, University Cadi-Ayyad of Marrakech, Morocco \\ ${ }^{2}$ Department of Plant Breeding, CEBAS-CSIC, PO Box 16430100 Espinardo (Murcia), Spain
}

Keywords:

argan tree /

Argania /

core collection /

genetic relationships /

RAPD /

Sapotaceae /

SSR /

taxonomy /

transferability

(Received 16 June 2008; accepted 8 September 2009)

\author{
Mots-clés : \\ arganier / \\ Argania / \\ collection noyau / \\ relations genetiques / \\ RAPD / \\ Sapotaceae / \\ SSR / \\ taxonomie / \\ transférabilité
}

\begin{abstract}
- The objective of this work is the molecular characterization of most common identified morphotypes of critically endangered rare Moroccan species Argania spinosa.

- Eighteen RAPD markers and twenty SSR markers have been assayed in 38 argan tree accessions from the three most commonly identified morphotypes: oval, spherical and spindle fruit types.

- A total of 140 polymorphic RAPD bands were detected out of 146 bands. The number of presumed alleles revealed by the SSR analysis ranged from 1 to 5 alleles per locus with a total number of 32 alleles identified. Results demonstrated an extensive genetic variability within the tested argan accessions. RAPDs presented a high level of polymorphism and greater information content than SSRs. - Our results could indicate that Vitellaria paradoxa is genetically closer to argan than Manilkara huberi. In addition, the correlation between the clustering based on RAPD and SSR markers were in general low. The observed clustering could be better explained according to geographic proximity than morphotype. For this reason the traditional morphological characterization of the argan accessions in morphotypes (according to fruit phenotype) seem not to be in correlation to the real genetic background (genotype) of this specie. The implications of these results in the creation of effective germplasm core collection in argan have been also discussed.
\end{abstract}

Résumé - Caractérisation moléculaire et relation génétique entre les morphotypes les plus connus d'une espèce marocaine rare et menacée, Argania spinosa (Sapotaceae) à l'aide de marqueurs RAPD et SSR.

- L'objectif de ce travail consiste en la caractérisation moléculaire et l'étude des relations génétiques entre des morphotypes identifiés chez une espèce marocaine rare et menacée, l'arganier (Argania spinosa).

- Pour cela, dix-neuf marqueurs RAPD et vingt marqueurs SSR on été testés dans 38 accessions d'arganier des trois morphotypes du fruit identifiés : ovale, sphérique et broche.

- En utilisant la technique d'amplification au hasard de l'ADN (RAPD), 140 fragments polymorphes ont été détectés parmi les 146 amplifiés. Le nombre d'allèle révélé par l'analyse des marqueurs microsatelittes (SSRs) varie de un à cinq allèles par locus avec un total de 32 allèles identifiés. Les résultats démontrent une grande variabilité génétique au sein des accessions d'arganier testées. Les marqueurs RAPD présentent un taux de polymorphisme et une hétérozygotie attendue supérieurs aux SSR.

- Les résultats indiquent également que Vitellaria paradoxa est plus proche génétiquement de l'arganier que Manilkara huberi. La corrélation entre les groupements observés dépend plus de la proximité géographique que de la classification selon la forme du fruit (morphotypes). La classification traditionnelle par morphotypes n'est donc pas en accord avec l'analyse génotypique chez cette espèce. L'apport de ces résultats pour la création d'une collection de référence chez cette espèce est discuté.

* Corresponding author: pmartinez@ cebas.csic.es 


\section{INTRODUCTION}

Argan [Argania spinosa (L.) Skeels], an endemic tree species from Southwest Morocco, belongs to the Sideroxyleae tribe of the tropical family Sapotaceae. It is the only representative of this family in Morocco. Argania is a monospecific genus with $A$. spinosa as the unique representative (Swenson and Anderberg, 2005). A. spinosa develops under the hot arid Mediterranean climate and has very different distribution and ecological preferences compared to the other species of the Sideroxylon tribe (Emberger, 1939). It occupies a wide distribution range (800000 ha) and has a great socio-economical and ecological role in these arid and semi-arid zones. The argan tree is valued for its highly unsaturated edible oil, wood, and forage. In addition, thanks to its powerful root system, it is valuable in land reclamation and fighting against desertification. However, a great zoo-anthropic action led to the absence of a natural regeneration (Benchakroun and Buttoud, 1989). The three most commonly identifed morphotypes of argan were oval, spherical and spindle fruit types (Bani-Aameur, 2004) (Fig. 1).

This species is genetically and molecularly very poorly known (Majourhat et al., 2007). Traditionally, characterization and identification of variability has been based on morphological (Bani-Aameur, 2004; Chernane et al., 2000) and biochemical (Chernane et al., 2000; El Mousadik and Petit, 1996a) markers. It has been suggested to use fruit form as criterion for varietal selection in this species (Bani-Aameur, 2004). However, such markers are not always available for analysis, and are affected by environmental conditions. DNA marker technology offers several advantages over the sole use of conventional markers. In the case of argan, only one work studying the genetic variability of argan populations using DNA amplification and restriction was published until now (El Mousadik and Petit, 1996b).

Random amplified polymorphic DNA (RAPD) markers are based on the PCR amplification of random locations in the genome (Messaoud et al., 2007; Welsh and McClelland, 1990). These markers are especially used in the molecular characterization of rare species including argan which are poorly known from the molecular point of view. The most crucial factor for this technique is the DNA quality and concentration offering the advantage of rapid screen for polymorphisms (Dax et al., 1993; Gérard et al., 2006). On the other hand, Simple sequence repeat (SSR) markers (microsatellites), also based on the PCR technique, are currently becoming the markers of choice for genetic fingerprinting studies because of their high polymorphism, co-dominance, multiallelism, abundance and uniform dispersion in plant genomes (de-Lucas et al., 2008; Gupta et al., 1996). However, to date, none of these markers have been described in argan although the ability to use the same microsatellite primers in different plant species from the same family, called transportability or transferability, has been well described (Decroocq et al., 2003).

The objective of this work is to present an appropriate set of RAPD and SSR markers suitable for the characterization of most common identified morphotypes of critically endangered rare Moroccan species Argania spinosa.

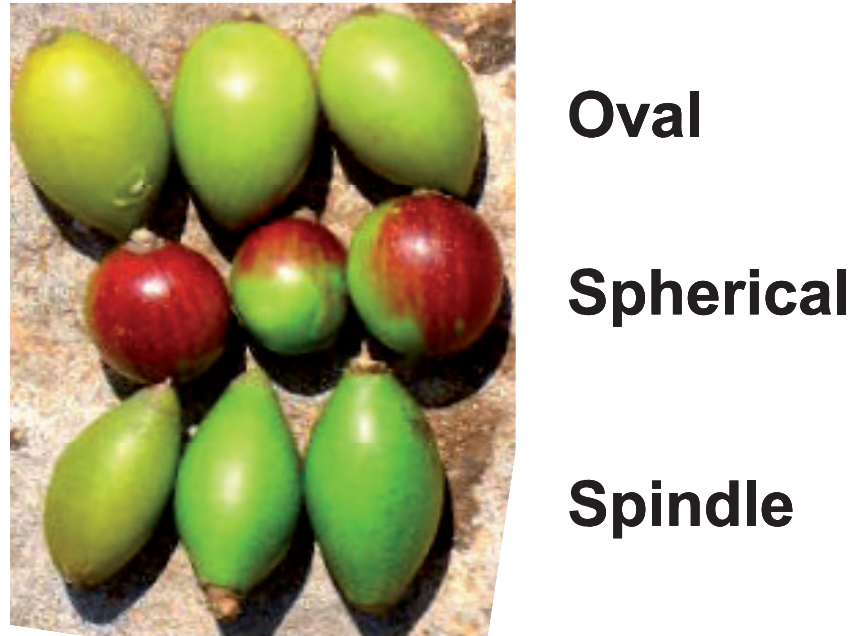

Figure 1. Most common identified morphotypes of the critically endangered rare species argan (Argania spinosa Skeel) assayed in this study: oval, spherical and spindle fruit types.

\section{MATERIAL AND METHODS}

\subsection{Plant material and DNA extraction}

Leaf material from 38 argan tree accessions growing in natural conditions was collected on May 2006 at Essaouira (Southwest of Morocco). The three most commonly identifed morphotypes of argan tree were sampled, oval, spherical and spindle fruit types (Fig. 1), together with some accessions of intermediate morphotypes.

Well expanded young leaves were used for DNA isolation using the procedure described by Doyle and Doyle (1987) using CTAB extraction buffer. DNA was quantified using a Biophotometer (Eppendorf, Barcelona, Spain).

\subsection{Development of RAPD markers}

Nineteen RAPD universal primers purchased from Operon Technologies (Huntsville, USA) were assayed (see supplemental data available Online only, Tab. A). Amplifications were carried out in $20 \mu \mathrm{L}$ total volume containing $1 \times$ Buffer (New England, Biolabs, Ipswich, USA), $1 \mathrm{mM} \mathrm{MgCl} 2,0.16 \mathrm{mM}$ of dNTP, $0.4 \mu \mathrm{mol}$ of primer, 1.0 unit of Taq DNA polymerase (Biolabs), and 4 ng templates DNA. The amplification program consisted of a step of DNA melting of 4 min at $94{ }^{\circ} \mathrm{C}$, followed by 35 cycles of $94{ }^{\circ} \mathrm{C}$ for $1 \mathrm{~min}, 35^{\circ} \mathrm{C}$ for $1 \mathrm{~min}$, and $72{ }^{\circ} \mathrm{C}$ for $1 \mathrm{~min}$, and a final elongation step of $72{ }^{\circ} \mathrm{C}$ for $10 \mathrm{~min}$. The amplified products were resolved in $2 \%$ agarose gels stained with ethidium bromide and visualized with UV transmitted light. A 1 Kb DNA Ladder (Invitrogen Life Technologies, Barcelona, Spain) was used as molecular size standard. RAPD amplifications were repeated at least twice in order to check the reproducibility of bands.

\subsection{Development of SSR markers}

Twenty SSRs developed in two different species inside the Sapotaceae family, 12 primer-pairs in Manilkara huberi (Ducke) 
Standl (Azevedo et al., 2005) and 8 additional ones in Vitellaria paradoxa C.F. Gaertn (Cardi et al., 2005) were tested for their transferability to amplify microsatellite loci in the 38 argan samples studied (Tab. I). PCRs were performed in $20 \mu \mathrm{L}$ mix containing $0.18 \mu \mathrm{M}$ each primer, $1 \times$ Taq buffer (Biolabs), $2.5 \mathrm{mM} \mathrm{MgCl} 2,0.1 \mathrm{mM}$ of each dNTP, 1 unit of Taq DNA polymerase (Biolabs), and approximately $5 \mathrm{ng}$ of DNA. The PCR program consisted of an initial melting step $\left(94^{\circ} \mathrm{C}, 4 \mathrm{~min}\right)$ followed by 30 cycles $\left(94^{\circ} \mathrm{C}, 30 \mathrm{~s}\right.$, annealing temperature, $30 \mathrm{~s}$ and $\left.72{ }^{\circ} \mathrm{C}, 1 \mathrm{~min}\right)$ and a final extension step $\left(72^{\circ} \mathrm{C}, 7 \mathrm{~min}\right)$. PCR products were separated using 3\% Metaphor Agarose gel electrophoresis (Biowittaker, Maine, USA). To confirm the results, SSR products smaller than 5 bp were also separated using $10 \%$ polyacrylamide gel electrophoresis (PAGE). A $1 \mathrm{~kb}$ DNA Ladder was also used as molecular size standard.

\subsection{Data analysis}

Polymorphic alleles were scored as present or absent (1/0). DNA band scoring was analyzed using GeneTools gel analysis software of SYNGENE (Beacon House, Nuffield Road, Cambridge, UK). The genetic diversity characterization was based on the number of alleles per locus in RAPDs and SSRs. The average polymorphic information content (PIC) was calculated for RAPD markers across assay units by applying the formula given by Powell et al. (1996).

The "genetic information content" of the codominant SSR markers was estimated by the observed heterozygosity $\left(\mathrm{H}_{o}\right)$, the expected heterozygosity $(\mathrm{He})(\mathrm{Nei}, 1978)$ using the POPGENE program (http://www.ualberta.ca/ fyeh/) and by power of discrimination (PD) (Kloosterman et al., 1993). On the other hand, mean character difference distances were calculated for all pairwise comparisons with the MEGA4 test (http://www.megasoftware.net/), which was used to construct UPGMA dendograms (cluster analysis) (Nei and Li, 1979) depicting the phenetic relationship among the different accessions. Relative support for the branches in each dendrogram was assessed with 2000 replicates of UPGMA bootstrap.

\section{RESULTS AND DISCUSSION}

The analysis of the 19 RAPD primers showed that all primers generated polymorphic and reproducible patterns. A total of 140 polymorphic RAPD bands were detected out of 146 bands with a size range between 322 and 2009 bp. The number of RAPD bands detected by each primer depends on primer, sequence and the extent of variation in specific argan genotype. The number of bands varied from 2 (for OPA-16) to 14 (for OPW-13), with an average of 7.8 bands per primer. The mean PIC score over all loci was 0.84 , ranging from 0.35 in OPA-16 to 0.96 in OPW-13 (see supplemental data, Tab. A and Fig. A).

In addition, amplification was successful with 4 of the 12 (33\%) SSR markers developed in Manilkara huberi and 7 of the $8(87 \%)$ SSR markers developed in Vitellaria paradoxa. A total of 32 polymorphic bands were scored for argan accessions. The number of presumed alleles revealed by the SSR analysis ranged from one to five with a size range of amplified bands between 129 and $278 \mathrm{bp}$. The observed heterozygosities ranged from 0.00 in Mh04, Mh07, Mh12, mVpCIRB03, and mVpCIRE04 to 0.60 in mVpCIRF05 SSR markers with an average of 0.18 . Mean expected heterozygosity was 0.59 , ranging from 0.00 in Mh12 to 0.80 in mVpCIRH04 (Tab. I and supplemental data Fig. A). In general the low heterozygosities values (observed and expected) showed in this study can be a consequence of the low number of argan accessions assayed which can also be genetically close according with the geographic proximity of the samples collected. For all the loci studied the expected heterozygosity was greater than the observed heterozygosity, implying the presence of null alleles or a deficit of heterozygotes due to non-random mating. The mean PD value for all loci was of 0.45 . The most informative loci were $\mathrm{mVpCIRF} 11$ and $\mathrm{mVpCIRH04}$ with a PD of 0.83 and the least informative were Mh12 and mVpCIRE04 wit a PD of 0.0 (Tab. I). These PD values are lower than those obtained in other assays with SSR (Shiran et al., 2007) as a consequence of the low polymorphism observed in the application of SSR in argan from relatively phylogenetically distant Sapotaceae species such as Manilkara huberi, as has been previously described in Prunus species by Martínez-Gómez et al. (2003). In the case of Vitellaria paradoxa PD are in general higher with higher level of SSR polymorphism indicating that this species is genetically closer to argan that Manilkara huberi. In addition, these PD values are in general lower than PIC values obtained in the other assays with RAPD as a consequence of the lower polymorphism observed in the application of SSR in comparison with RAPD, as has been previously reported in different species (de-Lucas et al., 2008; Lachenaud and Zhang, 2008; Messaoud et al., 2007; Shiran et al., 2007).

The level of polymorphism was slightly smaller in argan to that reported by Azevedo et al. (2005) and Cardi et al. (2005) in the original species in which the SSR markers were developed, i.e. Manilkara huberi and Vitellaria paradoxa respectively. However, the range of the amplified band sizes in argan was similar to those reported in the original species in which the SSR markers were developed. Overall, the results of the obtained polymorphism suggest a high degree of transportability of SSR in Sapotaceae family. These results agree with reports on the successful utilization of these markers in different species from the same genus (Martínez-Gómez et al., 2003) and the successful utilization of these markers in different species from the same family (Decroocq et al., 2003; de-Lucas et al., 2008).

Differences in amplification success for SSR markers observed among species are due to the genetic variability between the different species in Sapotaceae family where the SSRs were developed. A decrease in the amount of polymorphic SSR markers would be expected as genetic distance increases from the designated anchor species, as has been previously reported in Prunus by Martínez-Gómez et al., (2003). It has been shown that closely related species are more likely to share microsatellite priming sites than more distantly related ones, but it is possible to transfer functional microsatellite primers from more distantly related species in some cases (Lorieux et al., 2000). In this sense, these results also indicate that Vitellaria paradoxa is genetically closer to Argania spinosa than Manilkara huberi.

Using these two types of markers, the genetic distance among the argan accessions studied was studied. Phenetic 


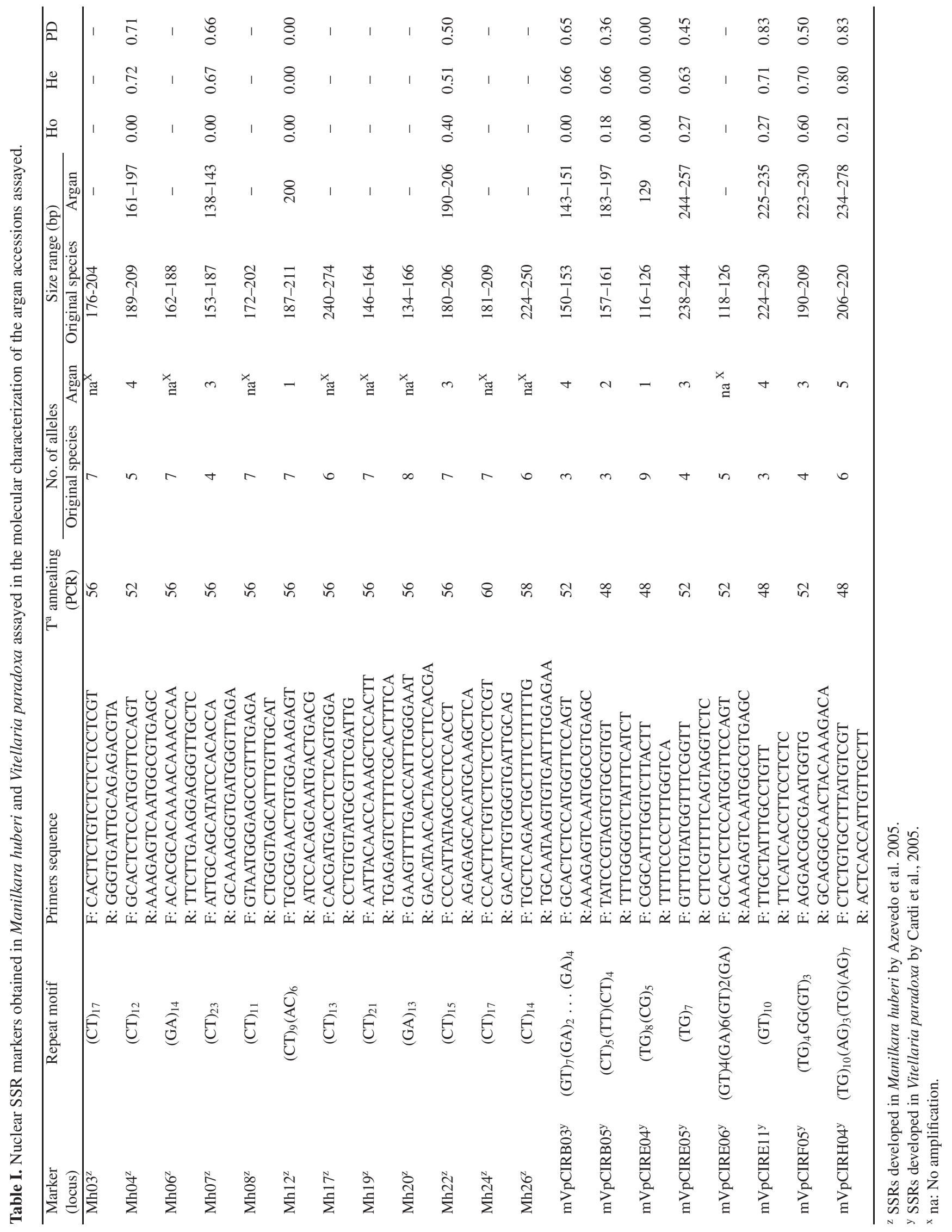


(taxonomy) relationships among argan morphotypes were analyzed with several UPGMA dendograms (see supplemental data, Fig. B). In general, both markers showed some degree of similarity in dendrogram topologies. Relationships moderately supported were similar in both cases, although with some differences in the positioning of some morphotypes in the main groups. However, bootstrap values of UPGMA dendrogram obtained with the utilization of RAPDs were slightly higher than those obtained using SSRs, in line with the larger number of observed bands with a higher polymorphism (Tab. I and supplemental data, Tab. A and Fig. A). Finally, the general dendrogram, constructed using the combined data sets (RAPDs+SSRs), was very similar to those obtained separately with each marker although with some differences with similar bootstrap values than the RAPD dendogram.

Dendrograms consist of some main clusters including some oval and spindle morphotypes which seem to be the two more important morphotypes from the molecular point of view. The remaining oval, spindle, spherical and intermediate morphotypes clustered out of these main clusters and in separately clusters. In addition, some well-supported clusters (according to bootstrap analysis) were established among some replications of some morphotypes using both markers (ie. sphericalal-5 and spherical-2; spindle-9 and spindle-10; spindle-4 and spindle-5; oval-11 and oval-12; oval-13 and oval-14; and oval-spindle-4 and oval-spindle-5).

In general no main groups were distinguished using these markers in relation to the morphotype groups. In some cases argan accessions from different morphotypes are closer than accessions from the same morphotype. This clustering could be better explained by geographic proximity than by morphotype as has been previously describe in a molecular study using chloroplast and mitochondrial DNA amplification (El Mousadik and Petit, 1996b). Traditional morphological characterization of the different argan accessions into morphotypes (according to fruit phenotype) does not correlate well with the real genetic background (genotype) of this species although main different morphotypes from the genetic point of view are oval and spindle fruit types. Morphotypes based on fruit morphology do not make up recognisable genetic entities based on molecular markers. On the other hand, the results obtained also confirm the great genetic diversity observed in argan using isoenzyme markers (El Mousadik and Petit, 1996a).

One of the goals of conservation programmes in these rare fruit species such as argan is to characterize and maintain existing level of genetic variation and genetic resources (Martínez-Gómez et al., 2007). Genetic resources not only provide the required raw material for suitable genetic crop improvement, but offer a unique gene combination to ensure adaptability and productivity (Lachenaud and Zhang, 2008; Wang et al., 2006). Designing of core collection involves an appropriate use of diversity, offering breeders an opportunity to work with a manageable number of accessions.

Acknowledgements: This work has been supported by grant A/6210/06 "Caractérisation biochimique et génomiques des morphotypes de l'arganier (Argania spinosa L. Skeels)" from the AECI (Agencia Española de Cooperación Internacional) of Spain.

\section{REFERENCES}

Azevedo V.C.R., Vinson C.C., and Ciampi Y., 2005. Twelve microsatellite loci in Manilkara huberi (Ducke) Standl. (Sapotaceae), an Amazonian timber species. Mol. Ecol. Notes 5: 13-15.

Bani-Aameur F., 2004. Morphological diversity of argan (Argania spinosa (L.) Skeels) populations in Morocco. For. Genet. 11: 311316.

Benchakroun F. and Buttoud G., 1989. L'arganeraie dans l'économie rurale du sud-ouest marocain. For. Méditerr. 2: 127-136.

Cardi C., Vaillant A., Sanou H., Kelly A., and Bouvet J.M., 2005. Characterization of microsatellite markers in the shea tree (Vitellaria paradoxa C.F. Gaertn.) in Mali. Mol. Ecol. Notes 5: 524-526.

Chernane H., Hafidi M., El Hadrami I., and Ajana H., 2000. Evolution des paramètres biométriques et de la composition en acides gras de l'huile de quatre types de fruits d'Arganier (Argania spinosa L. Skeels) durant la maturation. Agrochimica 44: 180-196.

Dax E., Livneh O., Edelbaum O., Kedar N., Gavish N., Karchi H., Milo J., Sela I., and Rabinowit H.D., 1993. A random amplified polymorphic DNA (RAPD) molecular marker for the Tm-2agene in tomato. Euphytica 74 (1-2): 159-163.

Decroocq V., Fave M.G., Hagen L., Bordenave L., and Decroocq S., 2003. Development and transferability of apricot and grape EST microsatellite markers across taxa. Theor. Appl. Genet. 106: 912-922.

De-Lucas A.I., Santana J.C., Recio P., and Hidalgo E., 2008. SSR-based tool for identification and certification of commercial Populus clones in Spain. Ann. For. Sci. 65: 107.

Doyle J.J. and Doyle J.L., 1987. A rapid DNA isolation procedure for small quantities of fresh leaf tissue. Phytochem. Bull. 19: 11-15.

El Mousadik A. and Petit R.J., 1996a. High level of genetic differentiation for allelic richness among population of argan tree (Argania spinosa (L.) Skeels) endemic to Morocco. Theor. Appl. Genet. 92: 832-839.

El Mousadik A. and Petit R.J., 1996b. Chloroplast DNA phylogeography of argan tree of Morocco. Mol. Ecol. 5: 547-555.

Emberger L., 1939. Aperçu général sur la végétation du Maroc. Commentaire de la carte phytogéographique du Maroc 1:1500000. Rubel E. et Lfidi W. (Eds.), Ed. Veröff. Geobot. Inst. Rfibel Zfirich, 14, pp. $40-157$.

Gérard P.R., Fernández-Manjarrés J.F., Bertolino P., Dufour J., Raquin C. and Frascaria-Lacostem F., 2006. New insights in the recognition of the European ash species Fraxinus excelsior L. and Fraxinus augustifolia Vahl. as useful tools for forest management. Ann. For. Sci. 63: 733-738.

Gupta P.K., Balyan H.S., Sharma P.C., and Ramesh B., 1996. Microsatellites in plants: a new class of molecular markers. Curr. Sci. 70: $45-54$.

Kloosterman A.D., Budowle B., and Daselaar P., 1993. PCRamplification and detection of the human DIS80 VNTR Locus. Amplification conditions and application in forensic analysis. Int. J. Leg. Med. 105: 257-264.

Lachenaud P. and Zhang D., 2008. Genetic diversity and population structure in wild stands of cacao trees (Theobroma cacao L.) in French Guiana. Ann. For. Sci. 65: 310.

Lorieux M., Ndjiondjop M.-N., and Ghesquière A., 2000. A first interspecific Oryza sativa and Oryza glaberrima microsatellite-based genetic linkage map. Theor. Appl. Genet. 100: 593-601.

Majourhat K., Jabbar Y., Araneda L., Zeinalabidini M., Hafidi A., and Martínez-Gómez P., 2007. Karyotype characterization of Argania spinosa (L.) Skeels (Sapotaceae). South Afr. J. Bot. 73: 661-663. 
Martínez-Gómez P., Arulsekar S., and Gradziel T.M., 2003. Relationships among peach and almond and related species detected by SSR markers. J. Am. Soc. Hort. Sci. 128: 667-671.

Martínez-Gómez P., Majourhat K., Zeinalabedini M., Erogul D., Khayam-Nekoui M., Grigorian V., Hafidi A., Piqueras A., and Gradziel T.M., 2007. Use of biotechnology for preserving rare fruit germplasm. Bioremediation, Biodiversity and Bioavailability 1: $31-40$.

Messaoud C., Afif M., Boulila A., Rejeb M.N., and Boussaid M., 2007. Genetic variation of Tunisian Myrtus communis L. (Myrtaceae) populations assessed by isozymes and RAPDs. Ann. For. Sci. 63: 845853.

Nei M., 1978. Estimation of average heterozigosity and genetic distance from a small number of individuals. Genetics 89: 583-590.

Nei M. and Li W.H., 1979. Mathematical model for studying genetic variation in terms of restriction. Proc. Natl. Acad. Sci. USA 76: 52695273.
Powell W., Morgante M., Andre C., Hanafey M., Vogel J., Tingey S., and Rafalski A., 1996. The comparison of RFLP, RAPD, AFLP and SSR (microsatellite) markers for germplasm analysis. Mol. Breed. 2: $225-238$.

Shiran B., Amirbakhtiar N., Kiani S., Sayed-Tabatabaei B.E., and Moradi H., 2007. Molecular characterization and genetic relationship among almond cultivars assessed by RAPD and SSR markers. Sci. Hortic. 111: 280-292.

Swenson U. and Anderberg A., 2005. Phylogeny, character evolution and classification of Sapotaceae (Ericales). Cladistics 21: 101-130.

Wang J.C., Hu J., Liu N.N., Xu H.M., and Zhang S., 2006. Investigation of combining plant genotypic values and molecular marker information for constructing core subsets. J. Int. Plant Biol. 48: 1371-1378.

Williams J.G.K., Kubelik A.R., Livak K.J., Rafalski J.A., Tingey S.V., 1990. DNA polymorphisms amplified by arbitrary primers are usefull as genetic-markers. Nucleic Acids Res. 18: 6531-6535. 


\section{Online Material}




\section{Supplemental data}

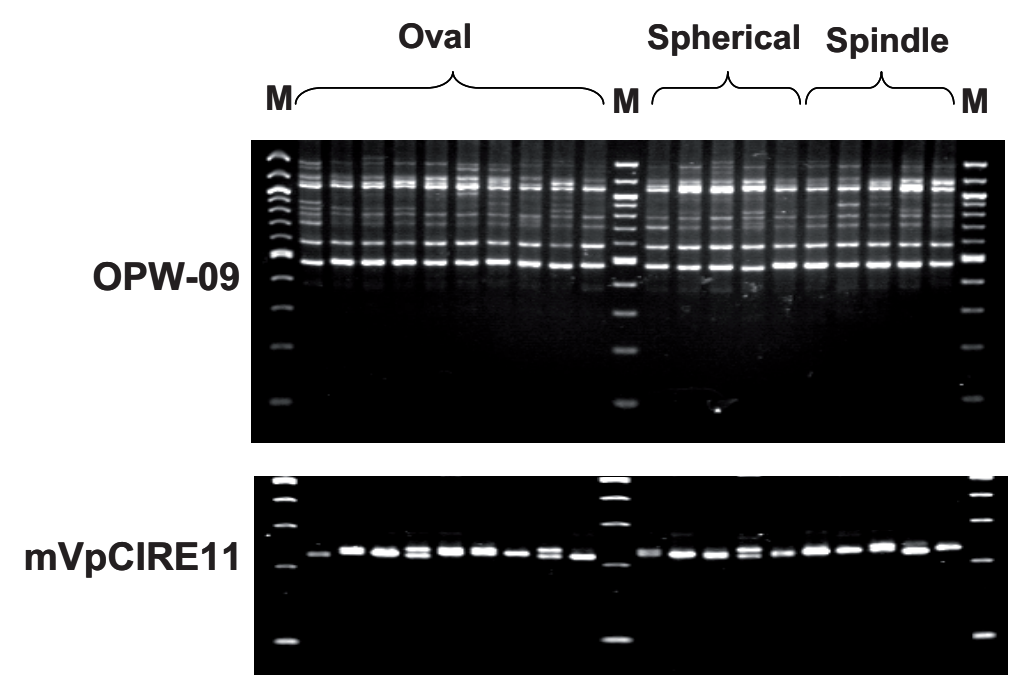

Figure A. Agarose gel (1.5\%) showing the allelic segregation of the OPW-09 RAPD marker and Metaphor ${ }^{\circledR}$ agarose gel (3\%) showing the allelic segregation of the mVpCIRE11 nuclear SSR marker. M, 1Kb DNA Ladder (Invitrogen, Madrid, Spain). 
RAPDs

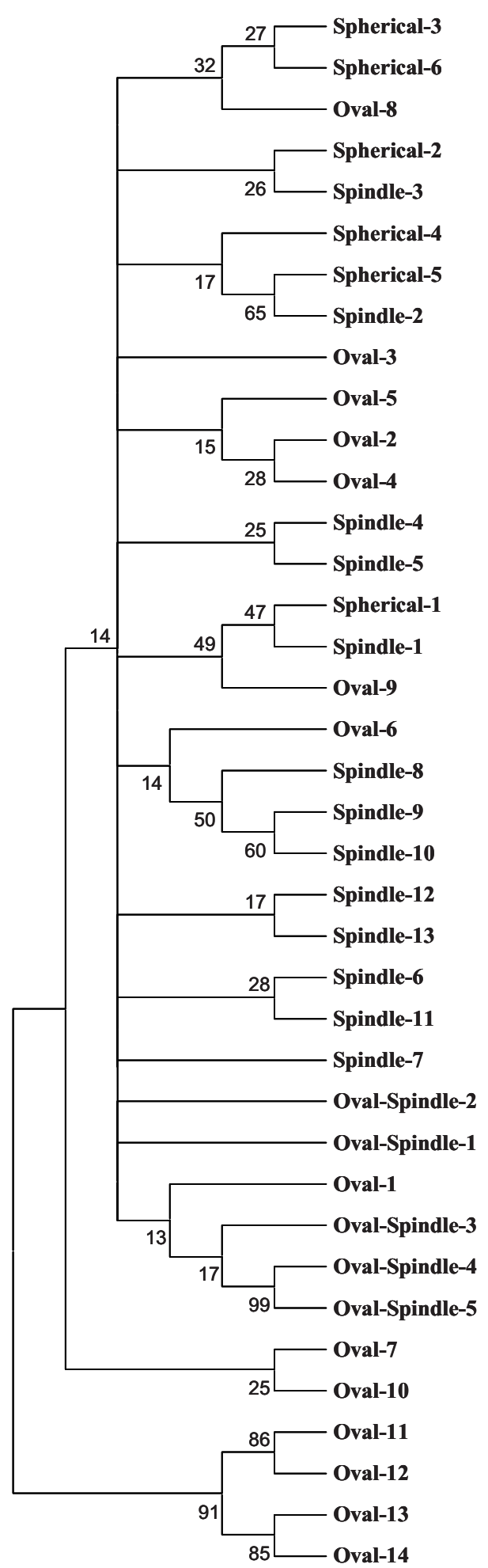

SSRs
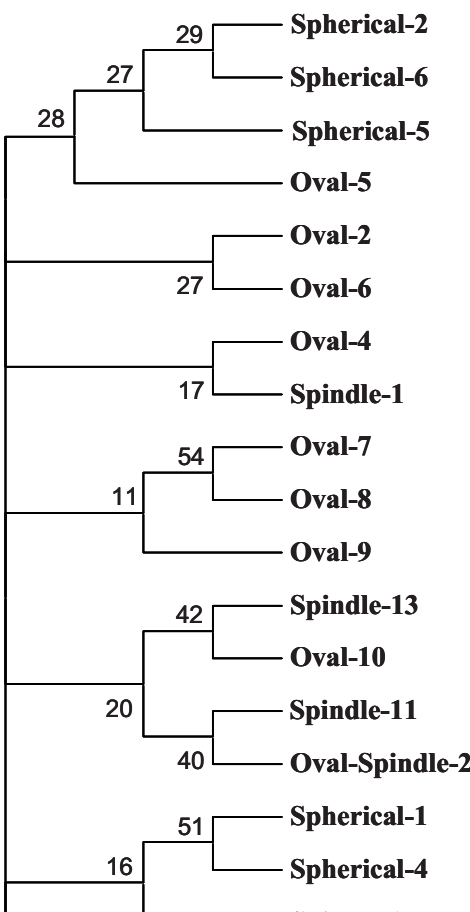

Spindle-2
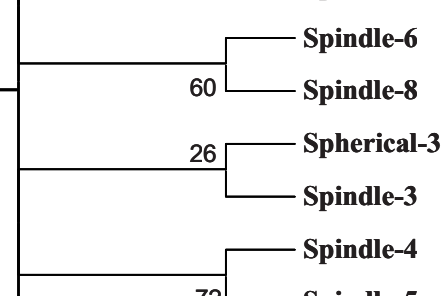

72 Spindle-5

Spindle-10

Spindle-9

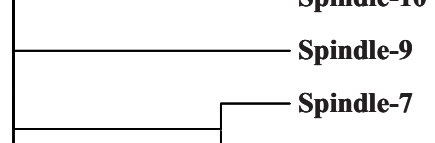

30 - Spindle-12
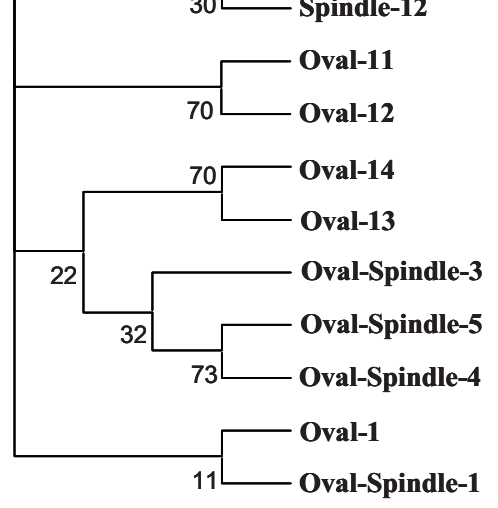

Oval-3
RAPDs+SSRs

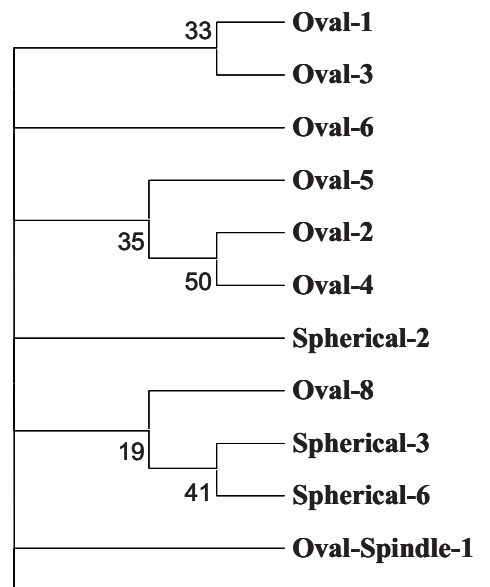

Spindle-13

Oval-Spindle-2

Spindle-11

10

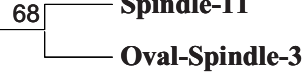

Oval-Spindle-4

$99 \leftarrow$ Oval-Spindle-5

75 Spindle-4

Spindle-5

Oval-9

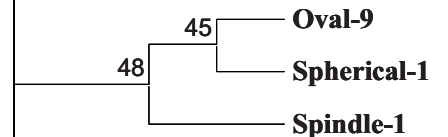

Spindle-1

Spindle-3

Spindle-7

Spindle-8

16

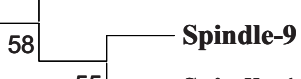

$55 \longleftarrow$ Spindle-10

Spindle-6

Oval-10

Oval-7

Spherical-4

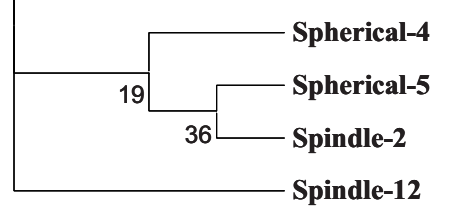

Oval-11

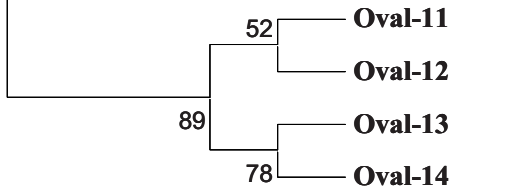

Figure B. Dendograms obtained by UPGMA cluster analysis based on mean character differences among the argan morphotypes (oval, spherical and spindle types) assayed in this study using RAPD and SSR markers separately and the whole data set of RAPD and SSR markers . Numbers in the branches represent bootstrap values. 
Table A. Universal primers (decamers) purchased from Operon Technologies Inc. (California, USA) used as RAPD markers molecular characterization of the argan accessions assayed.

\begin{tabular}{|c|c|c|c|c|c|c|}
\hline Marker & Primers sequence & $\mathrm{T}^{\mathrm{a}}$ annealing (PCR) & Number of bands & Number of polymorphic bands & Size range (bp) & PIC \\
\hline OPA-08 & GTGACGTAGG & 36 & 7 & 7 & $447-1413$ & 0.93 \\
\hline OPA-10 & GTGATCGCAG & 36 & 7 & 7 & $620-1839$ & 0.92 \\
\hline OPA-11 & CAATCGCCGT & 36 & 6 & 6 & $636-2514$ & 0.90 \\
\hline OPA-16 & AGCCAGCGAA & 36 & 4 & 2 & $1000-2009$ & 0.35 \\
\hline OPB-07 & GGTGACGCAG & 36 & 4 & 4 & $392-669$ & 0.83 \\
\hline OPB-11 & GTAGACCCGT & 36 & 7 & 7 & $589-2090$ & 0.88 \\
\hline OPG-13 & CTCTCCGCCA & 36 & 9 & 9 & $373-2553$ & 0.95 \\
\hline OPN-14 & TCGTGCGGGT & 36 & 7 & 7 & $548-1363$ & 0.91 \\
\hline OPN-15 & CAGCGACTGT & 36 & 9 & 8 & 349-2009 & 0.93 \\
\hline OPR-15 & GGACAACGAG & 36 & 7 & 7 & $615-1381$ & 0.93 \\
\hline OPR-16 & CTCTGCGCGT & 36 & 9 & 9 & $317-1844$ & 0.95 \\
\hline OPW-09 & GTGACCGAGT & 36 & 8 & 7 & $478-1075$ & 0.79 \\
\hline OPW-12 & TGGGCAGAAG & 36 & 5 & 5 & $521-1244$ & 0.83 \\
\hline OPW-13 & CACAGCGACA & 36 & 14 & 14 & 493-2001 & 0.96 \\
\hline OPX-03 & TGGCGCAGTG & 36 & 4 & 4 & $586-1875$ & 0.54 \\
\hline OPX-06 & ACGCCAGAGG & 36 & 11 & 11 & $444-2098$ & 0.92 \\
\hline OPY-06 & AAGGCTCACC & 36 & 8 & 8 & $447-1798$ & 0.92 \\
\hline OPY-13 & GGGTCTCGGT & 36 & 12 & 12 & $322-1683$ & 0.95 \\
\hline OPZ-09 & CACCCCAGTC & 36 & 8 & 7 & $531-1485$ & 0.89 \\
\hline
\end{tabular}

